4. Банщикова С.Л. Административная ответственность за неисполнение родителями или иными законными представителями несовершеннолетних обязанностей по их содержанию // Диссертация на соискание ученой степени к.ю.н. Омск. 2016. [Электронный ресурс]. - Режим доступа: https://lawbook.online/administrativnoe-pravo-rossii-kniga/osobennosti-sostavov-administrativnyih79728.html

5. Комендантский час для несовершеннолетних подростков [Электронный ресурс]. - Режим доступа: http://semeinoe-pravo.net/komendantskij-chas-dlya-nesovershennoletnih/

\title{
Павлова Е.В. \\ Отдельные аспекты определения административной ответственности в Российской Федерации на современном этапе
}

Орловский юридический институт МВД России имени В.В. Лукьянова (Россия, Орел)

doi: $10.18411 / s r-10-04-2021-82$

\section{Аннотация}

Осуществлен анализ теоретических и правовых основ определения административной ответственности в Российской Федерации в современный период развития государственности, сформулированы предложения о необходимости законодательного закрепления дефиниции административная ответственность.

Ключевые слова: правовое закрепление, административная ответственность, административное правонарушение.

\section{Abstract}

The analysis of the theoretical and legal foundations of the definition of administrative responsibility in the Russian Federation in the modern period of the development of statehood is carried out, proposals are formulated on the need for legislative consolidation of the definition of administrative responsibility.

Keywords: legal consolidation, administrative responsibility, administrative offense.

В современном мире назрела острая необходимость изучения и определения понятия «административная ответственность». Данное понятие является сложной и часто изучаемой категорией, которая нуждается в теоретическом осмыслении и правовом закреплении .

Согласно статье 2.3. Кодекса об административных правонарушениях Российской Федерации [1] административной ответственности подлежит лицо, достигшее к моменту совершения административного правонарушения возраста шестнадцати лет. В пункте втором этой же статьи говорится о том, что, с учетом всех конкретных обстоятельств, комиссией по делам несовершеннолетних лицо от шестнадцати до восемнадцати лет может быть освобождено от административной ответственности, но с применением к гражданину иной меры воздействия, предусмотренной федеральным законодательством о защите прав несовершеннолетних.

Проанализировав статью, можно прийти к выводу о том, что данная норма тесно перекликается с нормами других отраслей права, например, с уголовным. Так, Уголовный Кодекс [2] устанавливает общий возраст уголовной ответственности с шестнадцати лет, а за совершение отдельных видов преступлений даже с четырнадцати. Также можно привести пример и в сфере гражданских правоотношений, где имущественную ответственность за причинение того или иного вреда несут с четырнадцати до восемнадцати лет. Трудовой Кодекс [3] также устанавливает возраст лица, с которым можно заключить трудовой договор, который также составляет шестнадцать лет. 
Исходя из этого, необходимо сделать вывод о том, что законодатель считает лицо, которое, к моменту вступления в правоотношения в той или иной отрасли права, достигло шестнадцати лет, полностью способным и даже обязанным полностью осознавать весь социальный смысл своего поведения. Более того, данный гражданин обязан соблюдать и уважать не только свои права и обязанности, свободы, но и других лиц, ему необходимо верно оценивать свои действия и, тем более, отвечать за них и даже предвидеть наступления тех или иных благоприятных и неблагоприятных последствий.

Итак, если с возрастом наступления административной ответственности всё предельно ясно расписал законодатель, то с самим понятием не так всё просто. Следует учитывать, что административная ответственность является самостоятельным видом юридической ответственности и обладает определенным перечнем характерных особенностей. В частности к таковым можно отнести:

- административная ответственность рассматривается как определённый вид юридической ответственности, который по своей природе отличается от других видов ответственности, например, моральной, тем, что наказание гражданин будет нести за нарушение того или иного закона, чётко закреплённого в системе российского законодательства. Юридическая ответственность в данном случае представляет собой и как некое претерпевание назначенных мер принуждения и воздействия, и как определённая мера принуждения государства, которая безвозмездно будет применена к правонарушителю.

- при совершении правонарушения не учитывается субъективный критерий. Так, например, при совершении преступления Уголовный Кодекс учитывает такой признак преступления, как виновность, т.е. психическое отношение лица к совершённому преступлению. Если же лицо совершает правонарушение, например, нарушение правил дорожного движения, ответственность за которые предусмотрена главой 12 КоАП РФ, то совершенно неважно, сидел ли сам владелец авто за рулём или же кто - то другой, правонарушитель, т.е. собственник будет обязан выплатить штраф за совершённый манёвр.

- административная ответственность, в частности, её наступление невозможно без такой категории как административное правонарушение. Данное понятие является формально закрепленным и предусматривает, что оно может быть совершено как физическим, так и юридическим лицом.

- особый порядок осуществления производства по делу об административном правонарушении и как следствие привлечения к ответственности ( усеченное, обычное, усложненное производство), т.е. при незначительных финансовых издержках государства, потраченных на производство нарушитель претерпевает определенные негативные последствия за совершенный деликт.

- административная ответственность уникальна тем, что она может быть предусмотрена не только федеральной нормой, на законами субъектов Российской Федерации, предусматривающими такой вид ответственности [4, с.16].

Итак, все эти особенности помогают отличить такой вид юридической ответственности как административная ответственность от иных видов ответственности, закреплённых в системе законодательства Российской Федерации. 
Для того, чтобы более полно рассмотреть административную ответственность необходимо также выделить основополагающие признаки, на которых строится данная категория.

Одним из ключевых принципов административной ответственности является принцип законности, который предусматривает возможность привлечения лица к административной ответственности только на основе действующих норм федерального законодательства и законодательства субъектов российской Федерации, с учетом анализа всех обстоятельств дела об административном правонарушении.

Следующим, но не менее важным принципом, является принцип справедливости, который говорит о том, что совершённое административное правонарушение обязательно должно быть соразмерно административной ответственности. То есть за малозначительное правонарушение лицу не может быть назначен, например, административный арест, так как данная ситуация будет в полной мере нарушать принцип справедливости.

Главнейшим принципом демократии в современной России является принцип гуманизма, закрепляющий права и свободы человека и гражданина как высшую ценность. Данный принцип говорит о том, что назначенное правонарушителю наказание не может унижать человеческое достоинство, его честь, принадлежащие лицу права и свободы.

Следует в обязательном порядке отразить принцип презумпции невиновности, который предусматривает собой конституционно закрепленный постулат, что лицо в отношении которого ведется производство по делу об административном правонарушении не обязано доказывать факт своей невиновности, данное бремя ложится на должностное лицо, в производстве которого находится дело, не обязано свидетельствовать против себя и своих близких родственников. Однако, указанный принцип имеет некоторые особенности реализации в административном праве, в частности он частично не распространяется на административные правонарушения выявленные в режиме фото-видео фиксации.

Принцип своевременности, закрепляющий тот факт, что за совершённое тем или иным лицом правонарушение должна немедленно наступать административная ответственность и чем быстрее, тем лучше и эффективнее.

Делая вывод обо всём вышеизложенном, необходимо сказать о том, что административная ответственность [5,c.124] представляет собой самостоятельный вид юридической ответственности, который закреплён нормами административного права, наступающий в случае совершения лицом какого - либо правонарушения в сфере административных правоотношений, которое пресекается специально уполномоченным на то лицом в виде определённых административных наказаниях и в порядке, установленном законодательством. Данное умозаключение находит свое подтверждение и в положения Проекта кодекса Российской Федерации об административных правонарушениях, который впервые сформулировал формальное понятие административной ответственности указав, что ответственность наступает за совершение административного правонарушения, предусмотренного КоАП РФ или законом субъекта Российской Федерации об административных правонарушениях. [6]

$$
* * *
$$

1. Кодекс Российской Федерации об административных правонарушениях от 30.12 .2001 [Электронный ресурс] // СПС «КонсультантПлюс». - URL: http://www.consultant.ru. (дата обращения 04.03.2021)

2. Уголовный кодекс Российской Федерации от 13.06.1996 г. №63-Ф3 (ред. от 02.08.2019г.) [Электронный pecypc] // СПС «КонсультантПлюс». - URL: http:/www.consultant.ru. (дата обращения 04.03.2021)

3. Трудовой Кодекс Российской Федерации от 30.12.2001 г. № 197-Ф3 [Электронный ресурс] // СПС «КонсультантПлюс». - URL: http://www.consultant.ru. (дата обращения 04.03.2021) 
4. Кожевников Олег Александрович. К вопросу о понятии и признаках административной ответственности // Вестник Уральского юридического института МВД России. 2018. №1. URL: https://cyberleninka.ru/article/n/k-voprosu-o-ponyatii-i-priznakah-administrativnoy-otvetstvennosti (дата обращения: 26.02.2021).

5. Маркарян Петрос Карапетович. Понятие административной ответственности в науке и законодательстве // Проблемы экономики и юридической практики. 2010. №4. URL: https://cyberleninka.ru/article/n/ponyatie-administrativnoy-otvetstvennosti-v-nauke-i-zakonodatelstve (дата обращения: 26.09.2019).

6. Проект Федерального закона «Кодекс Российской Федерации об административных правонарушениях» (подготовлен Минюстом России 30.01.2020) [Электронный ресурс] // URL: http://base.garant.ru/56821718/ (дата обращения 04.03.2021) 